\title{
„„Jeśli umiecie - mówcie: kim jesteście?”. O Wiedźmach w wybranych polskich inscenizacjach Makbeta
}

\author{
„Speak if you can: what are you?": on the Witches \\ in selected Polish productions of Macbeth
}

\author{
|Tomasz Kowalski \\ Uniwersytet im. Adama Mickiewicza w Poznaniu \\ ORCID: 0000-0003-0262-0038
}

\begin{abstract}
The paper focuses on The Witches as they are depicted in Macbeth by William Shakespeare and in three Polish productions of the play from the first decade of the 21st century (directed by Andrzej Wajda, Grzegorz Jarzyna, and Maja Kleczewska). While pointing out an equivocal status of these characters in the tragedy, the author analyses selected scenes which present various ways of interpreting their encounters with the protagonist in contemporary perspective and suggests how literary education in school might benefit from referring to recent productions of Macbeth.
\end{abstract}

Key words: Shakespeare, Macbeth, The Witches, staging, adaptation, fantastic characters

Streszczenie: Rozważania prowadzone w artykule skupiają się na postaciach Wiedźm w Makbecie Williama Szekspira oraz trzech jego inscenizacjach z pierwszej dekady XXI wieku (wyreżyserowanych przez Andrzeja Wajdę, Grzegorza Jarzynę i Maję Kleczewską).

Wychodząc od niejasnego statusu postaci w samej tragedii, autor analizuje wybrane sceny ukazujące różne sposoby interpretowania ich spotkań z tytułowym bohaterem ze współczesnej perspektywy oraz sygnalizuje korzyści, jakie dydaktyka szkolna może czerpać z odwoływania się do współczesnych inscenizacji Makbeta.

Słowa kluczowe: Szekspir, Makbet, Wiedźmy, inscenizacja, adaptacja, postaci fantastyczne

Jedno z kluczowych zagadnień interpretacyjnych dotyczących Makbeta Williama Szekspira stanowi problem szeroko pojętego statusu tajemniczych postaci zapowiadających tytułowemu bohaterowi, że zasiądzie na szkockim tronie. Ich niepokojący wygląd i dwuznaczne wypowiedzi, sugerujące, że dysponują nadprzyrodzoną, niedostępną zwykłym ludziom wiedzą, a zarazem nasuwające podejrzenie, że zmyślnie manipulują nie tylko słowami, lecz także odbiorcami formułowanych przez nie przepowiedni - wszystko to wprowadza w konfuzję nie tylko słuchających ich Makbeta i Banqua, lecz 
także czytelników i widzów, z pewnością również tych, którzy zapoznają się z dziełem Szekspira po raz pierwszy jako z lekturą szkolną.

Niniejszy artykuł ma zatem na celu analize konkretnych przykładów scen i wątków z trzech realizacji Makbeta, które - jeśli odwołać się do nich w praktyce szkolnej - mogą rzucić nieco światła zarówno na wspomniane postaci, jak i rolę, jaką odgrywają w utworze, a jednocześnie wskazać różne sposoby interpretowania ich spotkań z tytułowym bohaterem ze współczesnej perspektywy. Wcześniej warto jednak przypomnieć kilka kwestii dotyczących sposobu funkcjonowania tajemniczych wieszczek w Szekspirowskiej tragedii.

Jej czytelnicy lub widzowie dysponują większą wiedzą na ich temat niż bohaterowie, są bowiem świadkami odbywanych przez nie potajemnie, na uboczu spotkań i znają treść toczących się w ich trakcie rozmów. Już w otwierającej tragedię scenie, kiedy zbierają się na pustkowiu i zmawiają na kolejne spotkanie, reagują na odgłosy wydawane przez kota i ropuchę ${ }^{1}$, co pozwala podejrzewać, z kim mamy do czynienia. Didaskalia określają owe postaci mianem Wiedźm, z czym doskonale współbrzmią, pojawiające się chwilę później (akt I, scena 3), składane sobie przez nie nawzajem relacje z rozmaitych złowrogich poczynań i rzucanych na ludzi uroków, będące „żywą ilustracją ustaw przeciw czarom i opisanych tam wiejskich zabobonów" (Cetera 2011, 25). Z tego repertuaru wyobrażeń obficie czerpie także fragment, w którym pojawiają się po raz ostatni (akt IV, scena 1), a więc słynna scena gotowania piekielnego wywaru², podczas której Makbet otrzymuje od zjaw kolejne przepowiednie.

Wyposażając postaci Wiedźm w rozpoznawalne wówczas powszechnie atrybuty czarownictwa, Szekspir wprowadzał do świata przedstawionego atmosferę tajemniczości oraz grozy, zarazem jednak odwoływał się do kwestii stanowiącej obiekt żywego zainteresowania widzów (szczególnie bliskiej samemu królowi - Jakubowi I) i rozpalającej ich wyobraźnię. Ten sensacyjny aspekt, choć istotny, nie powinien jednak przesłaniać faktu, że popularne w epoce relacje opisujące tajemnicze zjawiska lub działalność osób „parających się” demoniczną magią były dla ich odbiorców „o tyle ważne, że dobitnie potwierdzały (...) ówczesną, współdzieloną z innymi wizję świata na wskroś przenikniętego nadprzyrodzonością, która, jak wierzyli, nieustannie ujawniała swoją aktywną obecność" (Rutkowski 2012, 138). Przypisując zatem postaciom zwiastującym Makbetowi zdobycie tronu cechy pozwalające identyfikować je jako czarownice, autor tragedii zdaje się jednoznacznie wiązać je ze sferą zła.

1 To właśnie z tymi stworzeniami, zajmującymi ważne miejsce w „katalogu gatunków demonicznych zwierząt służących angielskim czarownicom jako ich "diabliki»" (Rutkowski 2012, 153), komentatorzy i tłumacze utożsamiają noszące w oryginalnym tekście konkretne imiona osobiste demony, do których zwracają się Wiedźmy.

2 Symboliczne znaczenie poszczególnych ingrediencji składających się na ten wyjątkowy przykład „szkockiej kuchni” oraz ich kulturowe i historyczne konteksty opisał w niezwykle pouczający, a zarazem wciągający sposób Jarosław Komorowski (2004, 532-545). 
Jak już wspomniano, publiczność wie więcej niż Makbet i Banquo, dla których pochodzenie zwiastujących im przyszłość postaci pozostaje zagadką. Mimo to sama nie jest w stanie zyskać pod tym względem całkowitej pewności. Potraktowanie ich jako Wiedźm, za sprawą demonicznej magii nawiązujących kontakt ze złymi duchami, nie wyczerpuje bowiem problemu ich „przedziwnej, eklektycznej tożsamości”, zwłaszcza że same nigdy tak o sobie nie mówią (Cetera 2011, 23). Zarówno Makbet, jak i Banquo, odnosząc się do nich, używają także określenia Weird Sisters, co wskazuje na ich konotacje z Losem (stąd m.in. „Siostry Losu” czy „Siostry Losem Rządzące” w polskich przekładach) i budzi oczywiste skojarzenia z antycznymi Parkami (a także anglosaską boginią Losu, Wyrdą). Wprowadza to do utworu - jak słusznie stwierdza Anna Cetera - „powiew metafizyki starego, pogańskiego świata i determinizmu, który go przenika. Siostry Losu są reliktem przeszłości i nie mają jednoznacznej konotacji etycznej” (Cetera 2011, 24).

Tę atmosferę dwuznaczności potęguje fundamentalne zdanie wypowiadane przez owe tajemnicze postaci $\mathrm{w}$ pierwszej scenie, ujmujące w syntetycznym skrócie istotę ich działalności. „Fair is foul, and foul is fair" (Shakespeare 1997, 103) - mówią Wiedźmy, łącząc w nieprzekładalnej w zasadzie frazie porządek estetyczny i etyczny, piękno i brzydotę z dobrem i złem³ ${ }^{3}$ Fragment ten zwraca uwage na zło, które „polega na odwróceniu znaczeń prowadzącym do zburzenia systemu wszelkich wartości" (Mroczkowska-Brand 2013, 292). Nadal jednak nie rozstrzyga o naturze postaci wypowiadających te słowa, a co za tym idzie - nie daje odpowiedzi na mnożące się pytania, stawiane zarówno przez bohaterów, jak i czytelników lub widzów.

Jedno z najistotniejszych tuż po pierwszym spotkaniu z Wiedźmami zadaje Banquo: „Czy to wszystko / Naprawdę się zdarzyło, czy też jakiś / Blekot opętał nam zmysły?" (Shakespeare 2013, 698). Pytania o to, do jakiego stopnia uznać postaci wróżące bohaterom świetlaną przyszłość za odrębne byty, na ile traktować je w sposób symboliczny, jako uosobienia Zła (metafizycznego, nadprzyrodzonego lub istniejącego wyłącznie w świecie), na ile zaś widzieć w nich nie tyle nawet urojenia, co projekcje najgłębiej skrywanych żądz i ambicji oraz zła czającego się w człowieku, stanowią podstawowe kwestie domagające się interpretacyjnych decyzji.

Problem ten, rozważany dotąd na płaszczyźnie tekstu, nabiera jeszcze większej wagi, gdy przychodzi zmierzyć się z jego teatralną lub filmową konkretyzacją - sposób, w jaki przedstawione zostają Wiedźmy, znacząco oddziaływa nie tylko na ocenę motywacji bohatera i podejmowanych przezeń decyzji, lecz także na całokształt aksjologicznego wymiaru danego odczytania. „Pomysł na Wiedźmy” staje się często jednym z podstawowych nośników

\footnotetext{
${ }^{3}$ „Nie tylko nieudolny, ale nawet bardzo dobry tłumacz nie będzie w stanie należycie oddać wieloznaczności tych słów i ich działających równocześnie różnych znaczeniowych konotacji” - komentował Henryk Zbierski $(1988,452)$, zwracając także uwagę na niemożliwe do oddania po polsku podobieństwo brzmieniowe obu wyrazów. Konsekwencje poszczególnych rozstrzygnięć translatorskich zastosowanych w polskich przekładach tragedii Szekspira (na przykładzie tłumaczeń Macieja Słomczyńskiego i Antoniego Libery) omawia szerzej Katarzyna Mroczkowska-Brand (2013, 279-293).
} 
znaczeń, jest istotną składową procesu adaptowania Szekspirowskiej wizji do współczesnych realiów i obrazu świata.

Warto zatem przyjrzeć się bliżej kilku przykładom takich rozwiązań, które poprzez szczególnie wyrazistą koncepcję interpretacyjną (niejednokrotnie wspomaganą różnego rodzaju zabiegami adaptacyjnymi) zwracają uwagę na aktualność znaczeń Szekspirowskiej tragedii albo pozwalają spojrzeć na jej tytułowego bohatera przez pryzmat zarówno uniwersalnych dylematów moralnych, jak i współcześnie postrzeganych procesów psychologicznych. Podstawę egzemplifikacji stanowić będą wybrane sceny $\mathrm{z}$ trzech inscenizacji Makbeta (wyreżyserowanych przez Andrzeja Wajdę, Grzegorza Jarzynę oraz Maję Kleczewską), powstałych w polskim teatrze w pierwszej dekadzie XXI wieku.

Makbet w reżyserii Andrzeja Wajdy ${ }^{4}$ zaczyna się od „kolejnego krajobrazu po bitwie" (Gruszczyński 2004) - scena zasłana jest czarnymi, plastikowymi workami, w których znajdują się zwłoki. To nie jedyne współczesne odniesienie. Postaci ubrane są w ciemne kostiumy, wyglądające jak umundurowanie bojowe oddziałów specjalnych. Nasuwa to oczywiste skojarzenia - przedstawienie powstało przecież niedługo po tym, jak polskie wojsko zaangażowane zostało $\mathrm{w}$ wojnę $\mathrm{w}$ Iraku. Po części uzasadnione jest więc stwierdzenie, że reżyser, "choć odżegnywał się od polityki w spektaklu, to jednak (...) wskazał wyraźnie obszary, których Szekspirowska tragedia może dotyczyć" (Guczalska 2004, 14). Tego rodzaju odczytanie nie unieważnia jednak zabiegów uniwersalizujących, podkreślających teatralność sytuacji - nadzwyczaj oszczędna scenografia utrzymana jest w ciemnych kolorach, dominuje w niej szarość i czerń, postaci zaś posługują się mieczami. Przychodząca na myśl bieżąca interwencja zbrojna jest więc w pewnym sensie po prostu jednym z ogniw ciągnącego się przez stulecia łańcucha rozmaitych wojen.

Wiedźmy wyłaniają się spośród zalegających na scenie trupów - worki służą im jako płaszcze, głowy przewiązane mają bandażami. Wypowiadają swoje przepowiednie, po czym znowu znikają wśród identycznie wyglądających ciał zawiniętych w folię. Zdają się jednymi z ofiar dopiero co zakończonej bitwy, być może jednak są raczej - jak proponuje krytyk - „duchami wojennego zniszczenia. Nie chcą, by wojna się skończyła, karmią się nią" (Gruszczyński 2004). Takie odczytanie może uzasadniać wprowadzona przez Wajdę kompozycyjna klamra, stanowiąca wyraźny zabieg interpretacyjny. Gdy Makbet zostanie już zabity, a akcja tragedii dobiegnie końca, scena znowu pokrywa się plastikowymi workami - powracamy do początku, historia zatacza koło, Wiedźmy zaś kończą spektakl, ponownie umawiając spotkanie: „Kiedy ta bitwa się rozegra / Kiedy ktoś wygra, a ktoś przegra. / O zmierzchu, o zachodzie słońca, / Kiedy ten dzień dobiegnie końca".

${ }^{4}$ William Shakespeare, Makbet, przekład: Antoni Libera, reżyseria: Andrzej Wajda, scenografia: Krystyna Zachwatowicz, muzyka: Stanisław Radwan, premiera: 26.11.2004, Narodowy Stary Teatr w Krakowie. 
Warto w tym miejscu choćby skrótowo odnieść się do koncepcji interpretacji postaci Makbeta i Lady Makbet, granych w tym spektaklu przez Krzysztofa Globisza i Iwonę Bielską, a więc parę starszą niż osoby zazwyczaj obsadzane w tych rolach. „Zrozumiałem, że Makbet i jego żona są ludźmi dojrzałymi. Makbet i Lady Makbet mordują, bo to ostatnia okazja, żeby z tego życia coś zgarnąć. I zrobią wszystko, żeby to uzyskać" (cyt. za: Guczalska 2014,12) - tłumaczył reżyser. W jego zamyśle przewodnie tematy przedstawienia miały współbrzmieć z problematyką znaną z powieści Fiodora Dostojewskiego i koncentrować się wokół sumienia, zbrodni i kary. Nie sposób tutaj szczegółowo odnieść się do tych założeń, w nie do końca zresztą udany sposób przekładających się na efekt końcowy - dość wspomnieć, że w recenzjach ze spektaklu regularnie pojawiają się uwagi dotyczące widocznych niespójności i niedostatków dramatycznego napięcia. Bez wątpienia jednak ciekawy efekt daje potraktowanie Makbeta jako „człowieka małego, ani dobrego ani złego, właściwie banalnego, którego zbrodnia nie czyni nihilistycznym straceńcem nie znającym już strachu i ludzkiej miary" (Gruszczyński 2014). Brnie on w zbrodnię, bo w zasadzie nic innego mu nie pozostało, choć jest w pełni świadomy konsekwencji, jakie go spotkają, a może nawet ich wyczekuje. Fakt, że spektakl ten - jak oceniała Guczalska - „składa się z ogniw: jedne są z lepszego, drugie z całkiem lichego kruszcu, ale nie tworzą łańcucha" (Guczalska 2014, 13), paradoksalnie ułatwia skorzystanie jedynie z poszczególnych fragmentów.

W kontekście roli odgrywanej przez Wiedźmy i ich wpływu na Makbeta niezwykle ciekawie jawi się sposób przedstawienia drugiego spotkania tych postaci. Stroje Wiedźm pozostają bez większych zmian, głos natomiast mają zwielokrotniony, odbija się on echem, budując atmosferę niezwykłości. Gdy bohater domaga się odpowiedzi na dręczące go pytania związane z jego dalszym losem, Wiedźmy proponują przekazanie jej „prosto od tych, którym jedynie służą”, po czym zaklinają: „Niewidzialne moce! W darze / Ujawnijcie swoje twarze”. Jako że Wiedźmy trzymają w rękach lustra, padające na nie światło odbija się i oślepia Makbeta.

Zastosowane w tym momencie rozwiązanie można czytać dwojako. Z jednej strony pozwala ono uniknąć kłopotliwego przedstawiania zjaw (ich kwestie wypowiadają poszczególne Wiedźmy), blask może zaś po prostu sugerować obecność sił nadprzyrodzonych. Z drugiej strony - słuszniejsze wydaje się połączenie tego zabiegu ze słowami: „on w twoich myślach sam swobodnie czyta", które padają w tym momencie. Makbet zatem spogląda w lustro, a tajemnicze moce, którym służą Wiedźmy, zdają się istnieć w nim samym, czerpać z jego własnych pragnień. Byłby to zatem wyraźny sygnał, że zbrodnie, których dokonuje, wynikają z jego własnych decyzji. To bez wątpienia jedna $\mathrm{z}$ najciekawszych interpretacyjnie scen $\mathrm{w}$ tym spektaklu - każe zastanowić się nad odpowiedzialnością bohatera za wyrządzone zło i stawia pod znakiem zapytania postrzeganie go jako efektu zewnętrznych 
podszeptów czy zrządzeń Losu (co zresztą interesująco współgra też z odniesieniami do konfliktów zbrojnych, od których zaczyna i którymi kończy się krakowski spektakl).

O ile w inscenizacji Wajdy nawiązanie do „wojny z terroryzmem” znajdowało się w sferze aluzji, o tyle u Grzegorza Jarzyny ${ }^{5}$ kontekst jest oczywisty. Jego 2007: Macbeth, stanowiący autorską adaptację tragedii Szekspira, utrzymaną w specyficznej, łączącej elementy filmowe i teatralne konwencji ${ }^{6}$, w całości osadzony został w realiach wojennych, na Bliskim Wschodzie. Główny bohater jest majorem armii amerykańskiej, dowodzi oddziałem komandosów, Banquo także jest oficerem, choć niższym rangą, Duncan natomiast - generałem. Początkową bitwę zastępuje brutalna i przeprowadzona wbrew zaleceniom akcja w meczecie - Macbeth i jego oddział „likwidują" modlącego się tam poszukiwanego terrorystę oraz jego towarzyszy (zabijając przy tym również przypadkowych wiernych), a następnie robią sobie zdjęcia z jego odciętą głową. Przykładów postępującej degeneracji moralnej bohaterów można znaleźć w tym spektaklu znacznie więcej - koszmar wojny z obcą cywilizacją staje się u Jarzyny „rodzajem bzika tropikalnego, który rozplenia się w bohaterach, zdzierając $\mathrm{z}$ nich powłokę cywilizowanych zachowań" (Targoń 2005, 42).

Z takim pomysłem adaptacyjnym - tutaj zarysowanym jedynie skrótowo - współgra ściśle sposób przedstawienia sceny pierwszej przepowiedni, którą jeszcze w meczecie, tuż po przeprowadzonej akcji, otrzymują Macbeth i Banquo. W spektaklu Jarzyny nie ma trzech Wiedźm, ich kwestie wypowiadają różne postaci - w tym momencie jest to Arabka, muzułmanka ubrana w czador, co stanowi ekwiwalent jej pochodzenia „z innego świata". W bohaterach budzi przede wszystkim lęk - cały czas trzymają ją na muszce, na jej czole widać nieustannie laserowy wskaźnik celownika, a kiedy znika, Banquo niemal mdleje, z napięcia słania się na nogach. Jej głos podlega elektronicznemu przetworzeniu, co wzmaga atmosfere grozy, a zarazem potęguje odczucie inności, tworzy kolejną - po etnicznej, religijnej i płciowej - płaszczyznę różnicującą obie strony sytuacji.

„Spektakl przede wszystkim pokazuje zło, które jest skutkiem wojny” - stwierdzała Joanna Targoń (2005, 42). Odwołanie do omówionej sceny może działać dwojako. Z jednej strony - za sprawą rekontekstualizacji Szekspirowskiej tragedii - może prowadzić do refleksji na temat wpływu wojny na żołnierzy biorących w niej udział, jak i na cywilne ofiary, zachęcać do przemyślenia przyczyn leżących u podłoża rozmaitych konfliktów zbrojnych, a także stanowić dobry punkt wyjścia do rozmowy o współczesnych odsłonach „zderzenia cywilizacji”, sposobach postrzegania Innego

5 2007: Macbeth, według Szekspira na podstawie tłumaczenia Stanisława Barańczaka, reżyseria i adaptacja tekstu: Grzegorz Jarzyna, scenografia i kostiumy: Stephanie Nelson, muzyka: Abel Korzeniowski, premiera: 19.05.2005, TR Warszawa.

6 Ten efekt - ze względu na zmianę medium - uległ oczywistemu przekształceniu, kiedy spektakl został sfilmowany w celu wydania go na DVD. Jako że obecnie funkcjonuje on w obiegu właśnie w tej wersji, warto zaznaczyć, że został on zarazem skrócony o niemal połowę, zmieniła się też część scen (podobnie jak muzyka), co jednak nie ma wpływu na prowadzone tu rozważania. 
oraz strachu, jaki niejednokrotnie budzi. Z drugiej - pozwala wrócić do samego tekstu, zastanowić się ponownie nad motywacjami Makbeta oraz miejscem, jakie wśród nich zajmuje właśnie strach, a co za tym idzie - rozpatrzyć możliwość, że zwiastujące mu zdobycie tronu Wiedźmy są (przynajmniej częściowo) emanacją jego psychiki.

Zupełnie inną, choć także określaną mianem filmowej estetyką posłużyła się w swojej wersji Makbeta Maja Kleczewska7, dokonując zresztą radykalnych cięć i przesunięć w tekście Szekspira ${ }^{8}$. Świat, który wykreowała, czerpie obficie ze współczesnej kultury masowej, przenika go duch filmów Davida Lyncha, Quentina Tarantino i Pedra Almodovara. Problematykę interesującą reżyserkę nadzwyczaj trafnie ujął w swojej recenzji Roman Pawłowski:

Jak przedstawić w teatrze zło, które osacza ze wszystkich stron współczesnego człowieka, atakuje go na ulicy blokowiska, w telewizyjnych transmisjach z Iraku i w kinie, w którym leci najnowszy przebój fabryki snów? Jakim językiem mówić o epidemii, której nie potrafią zatrzymać ani duszpasterze, ani wychowawcy, ani tym bardziej politycy? (Pawłowski 2004).

Jest to więc świat spsiały, krzykliwy, tandetny - przestrzeń współczesnego miasta. Duncan nie jest królem, a osiedlowym gangsterem otoczonym zgrają osiłków służących mu za ochronę, zamiast korony nosi złote sportowe buty. Impreza zorganizowana w domu Makbeta na jego cześć to ordynarna pijatyka, podczas której zacierają się hierarchie i puszczają hamulce, a „cały pierwszy akt tworzą klisze z filmów o gangach” (Pawłowski 2004).

$\mathrm{W}$ takich okolicznościach nie ma oczywiście miejsca na wiarę w przepowiednie, byty nadprzyrodzone czy Wiedźmy. Szukając dla nich ekwiwalentu, Kleczewska sięgnęła po postaci drag queens. Pomysł ten na pierwszy rzut oka może wydawać się nazbyt ryzykowny, warto jednak zauważyć, że wyraziście współbrzmi z niedookreślonym (także pod względem płciowym) statusem Wiedźm - w tekście Szekspira Banquo zwraca wszak uwagę na to, że wyglądają na kobiety, choć mają brody. „Wiedźmy najlepiej rozumieją reguły gry, a jednocześnie są z innej planety, z pogranicza światów, z dziwnego kontynentu, nierozpoznanego przez nas do końca, a przecież bardzo mocno istniejącego w naszej cywilizacji” (Dudek, Kleczewska 2004, 9) - tłumaczyła swój pomysł reżyserka.

Drag queens nie spotykają się tu na odludziu ani na wrzosowisku - gdy pojawiają się po raz pierwszy, siedzą na wysokich barowych stołkach na wysuniętym w stronę publiczności fragmencie proscenium. Ich przepowiednie są rzucane jakby mimochodem, nie do końca serio, z dużą dozą ironii - również Makbet i Banquo zdają się traktować je niezbyt poważnie, „jakby

${ }^{7}$ William Shakespeare, Makbet, przekład: Antoni Libera, reżyseria: Maja Kleczewska, scenografia: Katarzyna Borkowska, muzyka: Waldemar Wróblewski, premiera: 04.12.2004, Teatr im. Jana Kochanowskiego w Opolu.

${ }^{8}$ Nieco szerzej o tej strategii, polegającej na traktowaniu sztuk Szekspira jako „strukturalnego stelażu” przedstawienia, na którym osnuwane są „autonomiczne opowieści” odnoszące się do współczesnych doświadczeń, zastosowanej również w dwóch kolejnych szekspirowskich inscenizacjach Kleczewskiej (Śnie nocy letniej i Burzy) - zob. Kowalski 2014. 
to wszystko było wygłupem mieszczącym się w kategoriach zabawy. A jednak te słowa dają początek lawinie krwawych zdarzeń" (Kornaś 2004, 2).

W spektaklu Kleczewskiej są to postaci znacznie bardziej aktywne niż u Szekspira, towarzyszą scenom zbiorowym, biorą udział $\mathrm{w}$ imprezie u Makbeta. Chwilami zdają się pełnić rolę chóru, jak tuż przed wstrząsającą sceną zabicia Lady Macduff i jej dzieci, gdy żywiołowo tańczą w rytm I will survive, piosenki Glorii Gaynor, którą wykonują (co notabene odsłania ich popkulturową proweniencję, odsyła bowiem do filmu Priscilla, królowa pustyni). Tytuł tego utworu nie jest bez znaczenia, podobnie jak fakt, że drag queens wykonują go jeszcze raz w finale spektaklu, gdy Makbet zostaje zabity, który każe zastanowić się, co - i czy cokolwiek - poza złem jest tu w stanie ocaleć (por. Drewniak 2005). Jak pisał Tadeusz Kornaś, status tych postaci

pozostaje niepokojąco niejasny, jakby rzeczywiście przez nie (...) przelewało się coś niewyobrażalnego, trudno ubieranego w słowa, niosącego przesłanie czy przestrogę dla żyjących. Drag queens zapowiadają sytuację - która z miażdżącą konsekwencją musi się spełnić i która tak naprawdę zawiera w sobie zasady podstawowych mechanizmów życia społecznego (Kornaś 2004, 4).

Tak potraktowane postaci Wiedźm, jeśli odnieść je do Szekspirowskiej tragedii, mogą budzić zdumienie, a nawet sprzeciw. Kleczewska czyta jednak Makbeta bardzo konsekwentnie - zło w jej spektaklu nie jest domeną sił nadprzyrodzonych, obecne jest zarówno w świecie, jak i w bohaterach. Nie potrzeba wcale wiele, by ujawniło się i nabrało rozmachu.

Fakt, że Makbet jest tu sportretowany jako przeciętny, nie wyróżnia się specjalnie i chce po prostu wykorzystać nadarzającą się okazję, zanim ktoś inny go ubiegnie, po raz kolejny zwraca uwagę na problem motywacji bohatera, uwydatnia jego decyzyjność. Umożliwia też przyjrzenie się jego dynamice: zmianom, jakie $\mathrm{w}$ nim zachodzą, i sposobom zachowania w nowych sytuacjach - kto wie, czy nie łatwiejsze niż w przypadku bezpośredniej konfrontacji z tragedią Szekspira, której sensy (zwłaszcza gdy czyta się ją w dawniejszych przekładach) mogą zdawać się odległe, przesłonięte historycznym dystansem. Nie do przecenienia może też okazać się możliwość postawienia pytania o obrazy przemocy i zbrodni w kulturze masowej czy dyskursie medialnym (trudno bowiem udawać, że uczniowie nie mają z nimi kontaktu), a także mechanizmy prowadzące do znieczulenia na nie.

Dokonany tu przegląd może okazać się przydatny w kontekście szkolnej praktyki lekturowej, w której nigdy dość podkreślania, że pierwotnym przeznaczeniem tekstu dramatycznego jest realizacja sceniczna. Na powszechność tego problemu zwracał uwagę Marek Pieniążek, stwierdzając, że

dramat wpuszczony w uproszczoną strukturalno-semiotyczną maszynkę szkolnej interpretacji na każdej lekcji natychmiast zatraci walory performatywnej potencjalności (bądź walory żywego widowiska) wraz z tak ważnymi dla ucznia jakościami jak: uczestnictwo, emocja, utożsamienie, pragnienie naśladowania postaci itp. $(2012,407)^{9}$.

${ }^{9}$ Formułowane przez Pieniążka uwagi pochodzą wprawdzie z okresu, w którym istniały jeszcze gimnazja i odnoszą się do zapisów nieaktualnej już podstawy programowej, nie straciły jednak (niestety) na aktualności pod pozostałymi względami. 
Wymieniając inne mankamenty szkolnej lektury dramatów Szekspira, badacz wspomina o sprowadzaniu ich bardzo często do roli „rezerwuaru gotowych motywów i symboli”, traktowaniu ich bohaterów jako „postaci niezaobserwowanych w dramatycznym działaniu, ale w dookreślonej raz na zawsze strukturze i wizerunku", a także mechanicznym wiązaniu dramatu z tragizmem (Pieniążek 2012, 418).

Odwołanie się do przywołanych przykładów może pomóc w wydobyciu się z tego rodzaju kolein, trzeba jednak zarazem podkreślić, że nie jest to w żadnym razie katalog zamknięty, wręcz przeciwnie - warto go nieustannie poszerzać. Podobnie można by zresztą prześledzić inne postaci i wątki, chociażby sposób przedstawiania Lady Makbet i jej wpływu na bohatera, a także kierujące nią pobudki ${ }^{10}$, co jest równie fascynującym tematem, ale wymagałoby osobnego artykułu. Skonfrontowanie uczniów ze współczesnymi realizacjami scenicznymi Makbeta (odnosi się to oczywiście w równym stopniu do wszystkich dramatów omawianych w szkole) stwarza okazję do podjęcia dyskusji na temat aktualności tekstu, przyjrzenia się współczesności przez jego pryzmat lub postawienia pytania o granice reżyserskich ingerencji w dzieło.

Skupienie się na postaciach Wiedźm i ich interakcjach z głównym bohaterem oraz roli, jaką odgrywają w poszczególnych inscenizacjach, może mieć jednak jeszcze jeden cel: zaakcentowanie faktu, że Makbet sam podejmuje decyzje o zabiciu Duncana i kolejnych zbrodniach, w każdej chwili bowiem mógłby postąpić inaczej. Na ten aspekt warto zwracać uwagę, zwłaszcza że (zapewne wbrew nauczycielskim staraniom) bohater nazbyt często jawi się uczniom jako zdeterminowany przepowiedniami, przez co utwór Szekspira odruchowo - choć błędnie - traktują oni w kategoriach antycznej tragedii losu, widząc w Wiedźmach (na co zresztą wydatnie wpływa określanie ich wspomnianym już mianem „Sióstr Losem Rządzących”) wcielenie siły nazywanej zwyczajowo Fatum.

Jeśli więc Szekspirowskie Wiedźmy wprowadzają zamęt również pod tym względem, w myśl przytaczanej wcześniej dewizy „fair is foul, and foul is fair", warto przypomnieć, że pierwsze słowa wypowiadane przez Makbeta (jeszcze przed spotkaniem z Wiedźmami) brzmią: „Pierwszy raz w życiu widzę dzień tak szpetny [foul], a tak świetności pełen [fair]" (Shakespeare 2013, 698). Zło drzemie już w nim samym.

\section{Bibliografia:}

Cetera Anna, 2011, Makbet, czyli wylęgarnia skorpionów, w: Shakespeare W., Makbet, Kamiński P. (przeł.), Warszawa.

Drewniak Łukasz, 2005, Eksplozja zła, „Newsweek”, nr 6.

10 Ciekawym przykładem, tym razem nie teatralnym, a filmowym, w którym znaleźć można sporo intrygujących rozwiązań dotyczących zarówno postaci Wiedźm, jak i Lady Makbet (zwłaszcza w odniesieniu do wprowadzonego tam wątku straty dziecka), jest adaptacja Makbeta z 2015 roku, wyreżyserowana przez Justina Kurzela. 
Dudek Katarzyna, Kleczewska Maja, (2004), Wyjątkowo okrutna rzeczywistość [rozmowa], „Didaskalia. Gazeta Teatralna”, nr 64.

Gruszczyński Piotr, 2004, Wiedźmy wojny, „Tygodnik Powszechny”, nr 50.

Guczalska Beata, 2004, „Makbet” w próżni, „Didaskalia. Gazeta Teatralna”, nr 64.

Komorowski Jarosław, 2004, Piekielny rosół, czyli kuchnia szkocka, w: Fabiszak J., Gibińska M., Nawrocka E. (red.), Czytanie Szekspira. Interpretacje, Gdańsk.

Kornaś Tadeusz, 2004, Makbet wielkiego miasta, „Didaskalia. Gazeta Teatralna”, nr 64.

Kowalski Tomasz, 2014, Pre(-)tekst - Szekspir Mai Kleczewskiej, w: Kujawińska-Courtney K., Sosnowska M. (red.), Shakespeare 2014. W 450. rocznice urodzin, Łódź.

Mroczkowska-Brand Katarzyna, 2013, „Złe dobre jest, a dobre - złe”. Konsekwencje interpretacyjne przekładu kluczowego cytatu $z$ "Makbeta”, „Ruch Literacki", nr 3.

Pawłowski Roman, 2004, Ciężkie zbrodnie popkultury, „Gazeta Wyborcza”, nr 288, https://encyklopediateatru.pl/artykuly/6765/ciezkie-zbrodnie-popkultury (dostęp: 23.10.2021).

Pieniążek Marek, 2012, Tragizm, wiedźmy i Elsynor : co Szekspir mówi dzieciom we współczesnej szkole, w: Łubieniewska E., Latawiec K., Waligóra J. (red.), Szekspir wśród znaków kultury polskiej, Kraków.

Rutkowski Paweł, 2012, Kot czarownicy. Demon osobisty w Anglii wczesnonowożytnej, Kraków.

Shakespeare William, 2013, Tragedie i kroniki, Barańczak S. (przeł.), Kraków.

Shakespeare William, 1997, Macbeth, Braunmuller A.R. (oprac.), Cambridge.

Targoń Joanna, 2005, Macbeth. The movie, „Didaskalia. Gazeta Teatralna”, nr 67-68.

Zbierski Henryk, 1988, William Shakespeare, Warszawa.

\section{O Autorze:}

Tomasz Kowalski - dr, adiunkt w Katedrze Teatru i Sztuki Mediów UAM; nauczyciel języka polskiego w Liceum św. Marii Magdaleny w Poznaniu. Jego zainteresowania badawcze skupiają się na życiu i twórczości Williama Szekspira oraz adaptacjach jego dzieł, historii teatru elżbietańskiego, a także na współczesnym teatrze polskim. Autor monografii William Shakespeare - fikcja $w$ biografiach, biografia $w$ fikcjach (2018); W.H. Auden - szekspirolog i librecista (2019) oraz artykułów w tomach zbiorowych i czasopismach. 